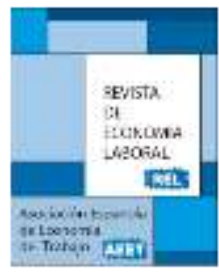

\title{
DIGITAL LABOUR PLATFORMS: A NEED FOR INTERNATIONAL REGULATION?
}

\author{
Janine Berg*, Miriam A. Cherry** and Uma Rani* \\ * International Labour Office, Geneva Switzerland ${ }^{1}$. \\ ** Saint Louis University Law School, St. Louis, Missouri, USA.
}

Recibido Septiembre 2019; Aceptado Diciembre 2019

\begin{abstract}
Web-based, digital labour platforms permit the real-time hiring of labour for a myriad of tasks from IT programming to graphic design to routine clerical tasks. The ease, flexibility and low-cost of outsourcing work to digital labour platforms has resulted in their growth, and this growth is likely to continue in the future. Yet these online activities pose important regulatory challenges that cannot effectively be addressed solely through national responses. Recognizing these difficulties, the ILO's Global Commission on the Future of Work called for an international governance system for digital labour platforms that could set and require platforms, and their clients, to respect certain minimum rights and protections for all workers. This paper will discuss the prospects and challenges inherent in cross-border, web-based, digital labour platforms for workers, operators, and regulators and put forward possibilities for establishing an international regulatory framework for these new forms of work
\end{abstract}

Key words: digital labour platforms, transnational regulation

JEL Classification: J08, J53, J81

${ }^{1}$ The views expressed are our own and do not necessarily reflect those of the ILO. Email: berg@ilo.org

(C) Revista de Economía Laboral 


\section{Resumen}

Las plataformas laborales de trabajo, alojadas en Internet, permiten la contratación de trabajo en tiempo real para multitud de tareas, desde la programación al diseño gráfico o tareas administrativas rutinarias. La facilidad, flexibilidad y bajo coste de subcontratar trabajo a través de estas plataformas digitales explican su crecimiento, que se prevé que continúe en el futuro. Sin embargo, estas actividades en línea suponen importantes retos regulatorios que no pueden ser abordados únicamente mediante respuestas nacionales. Reconociendo estas dificultades, la Comisión Mundial de la OIT sobre el Futuro del Trabajo recomendó el establecimiento de un sistema de gobernanza internacional que pudiera establecer y requerir a las plataformas digitales - y a sus clientes - respetar ciertos derechos minimos y protección para todos los trabajadores de plataformas. Este artículo discute las perspectivas y retos inherentes en las plataformas digitales internacionales en línea para los trabajadores, operadores y reguladores, y formula propuestas para el establecimiento de un marco regulatorio internacional para estas nuevas formas de trabajo.

Palabras clave: plataformas laborales de trabajo, regulación transnacional Clasificación JEL: J08, J53, J81 


\section{Introduction}

Debates on the gig economy have tended to focus on transportation network companies (TNCs) and other types of locally provided services, likely due to the greater visibility of this work. What is less discussed, but of nonetheless growing importance in the world of work, are cross-border, web-based, digital labour platforms (also known as "crowdwork" platforms). These online activities pose regulatory challenges for nationally-based systems of labour and employment law.

Web-based, digital labour platforms permit the real-time hiring of labour for a myriad of tasks from IT programming to graphic design to routine clerical tasks. On these platforms, groups of workers ("the crowd") living across multiple time zones offer businesses the possibility of completing projects at any time of day or night, and large numbers of workers mean that tasks can be accomplished quickly. Leveraging the power of "the crowd," a business can have access to thousands of workers who can perform a disparate array of activities.

Crowdwork platforms, like most other types of digital labour platforms, often seek to label their workers as independent contractors or as self-employed, resulting in a lack of labour protections and employer-provided social security benefits. The matter of classification has not been decided by courts, and may not be an accurate statement as to a worker's status. The terms and conditions of working on the platforms are laid out in the platforms' "terms of service" documents, which workers must accept in order to begin working. These terms are set unilaterally by the platforms and state how and when crowdworkers will be paid, how their work will be evaluated, and what recourse workers have (or do not have) when there are problems. At times these terms are not accurate statements of worker's rights, and yet those workers reading the documents may not understand that they may have other recourse.

As workers on crowdwork platforms are spread throughout the world, and many live in different countries from where the platform or the clients are located, it is not a simple matter for national regulators to address working conditions. The terms of service may label workers as independent contractors, depriving the workers of the right to organize collectively, a prerogative granted under many nations' laws only to employees. Moreover, even if they could organize, the geographic dispersion of the workforce would make it difficult. This paper will discuss the prospects and challenges inherent in cross-border, webbased, digital labour platforms both for workers and regulators. It will put forward possibilities for establishing an international regulatory 
framework for these new forms of work. The paper is organised as follows. The next section provides a brief description of the structure and operation of digital labour platforms. Section 3 discusses the opportunities and risks for workers in these online web-based digital platforms. Section 4 lays out the potential difficulties and challenges in regulating digital labour platforms across multiple jurisdictions, and puts forward a proposal for an international governance system for digital labour platforms in Section 5. The final section concludes.

\section{Digital labour platforms: Structure and operation}

In the mid-2000s, Amazon launched its first crowdworking platform as a way to service its growing on-line catalogues. The company found that its computer programmes were unable to distinguish between similar products leading to errors and multiple entries on the Amazon site; it thus needed human labour to correctly tag and classify its catalogue entries. Originally the tasks on the platform were designed for Amazon employees to do in their 'spare time', but the company soon realized that it could externalize the tasks to a crowd of workers across the globe, as well as provide a platform for other companies to post tasks. Ironically, it is the failures of artificial intelligence that spurred the need for human input, leading Jeff Bezos, head of Amazon, to aptly describe the Amazon Mechanical Turk (AMT) platform as "artificial-artificialintelligence" (Irani, 2015). Despite important advances in artificial intelligence, the need for human intelligence to service an ever-ranging array of activities to ensure the smooth functioning of automated or "artificially intelligent" systems continues to grow, with no sign of abating (Corporaal and Lehdonvirta, 2017; Schmidt 2019; Gray and Suri, 2019) ${ }^{2}$.

By the early 2010s, further technological advances, especially in GPS as well as the development and diffusion of smartphones, led to the proliferation of location-based, digital labour platforms whereby an app is used to match labour demand and supply within a particular geographic space. These "work-on-demand" labour platforms typically involve physical activities and services that are performed locally include transportation, delivery and home services. Figure 1 distinguishes between the location-based, labour platforms, some of which (for

\footnotetext{
${ }^{2}$ Gray and Suri (2019) refer to this as the "paradox of automation's last mile".
} 
example, Uber, Foodora, Deliveroo) have been the subject of intense debate, and the web-based, crowdwork platforms whereby the work is posted on on-line and a worker located in any part of the world with a reliable internet connection, can access the work, perform it, submit it and receive payment.

Figure 1. Categorization of digital labour platforms. (Source: Adapted from Schmidt (2017)).

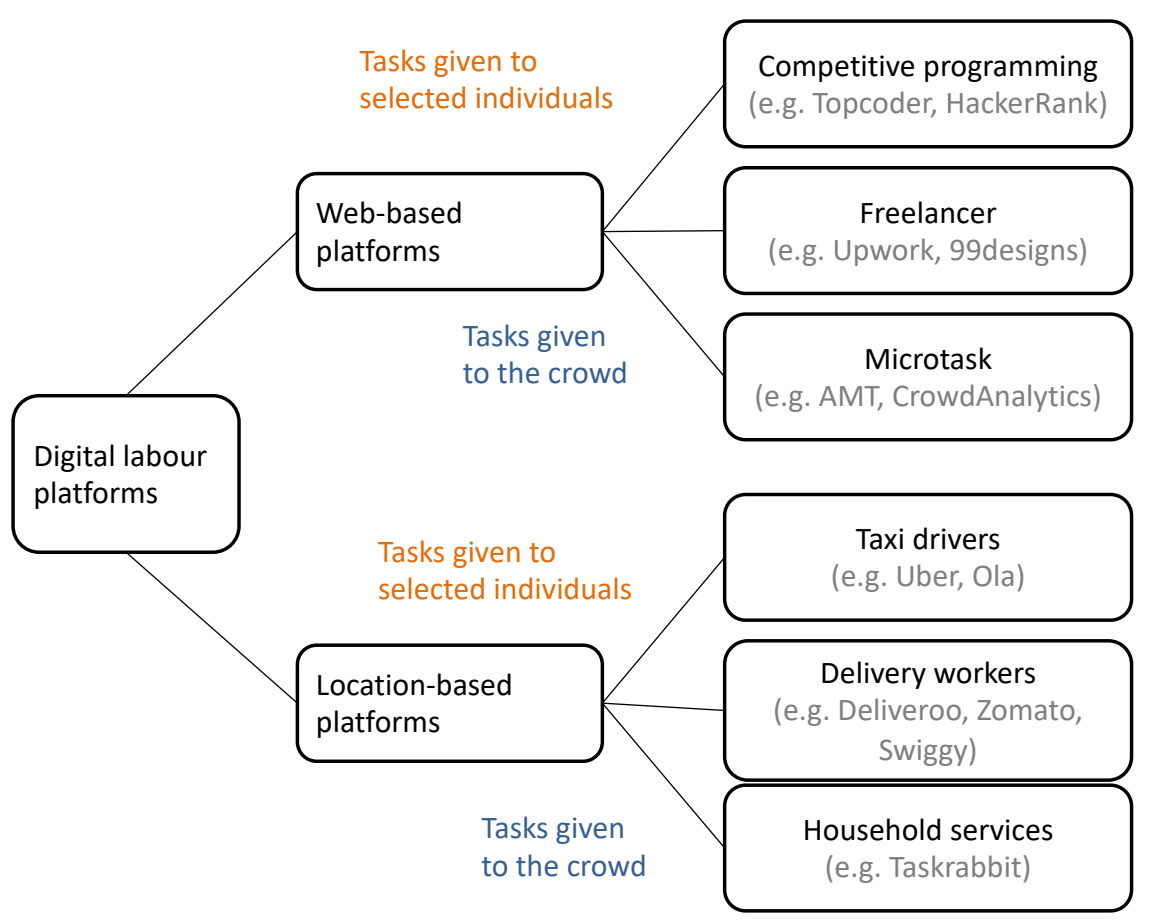

Both types of digital labour platforms mediate work or services delivered between service providers and customers. Thus, there are typically three parties in the relationship: the requester or client seeking services, the intermediary (the platform), and the workers. While digital labour platforms present major differences, all of them perform three specific functions: (1) matching workers with demand for their services; (2) providing a common set of tools and services that enable the delivery of work in exchange for compensation; and (3) setting rules through their terms of service agreement (Choudary, 2018). These terms of service agreements reflect the decisions made by individual platforms on how in 
what context participants on the platform are exposed to each other, the information that is collected, how the information is displayed, the trades that are permissible, who can participate, how entry is gained, the contracts and prices allowed, as well as how disputes will be handled (Agrawal et al., 2013). Despite these similarities, digital labour platforms differ in their architecture, with some offering the exchange of highly substitutable or highly standardized work (platforms such as Uber or Clickworker), whereas others offer a space for workers to develop more specialized services and build a network (see for example, TopTal). As a result, the architecture of the platform has important implications for workers' autonomy, as well as their working conditions and earnings (Choudary, 2018).

Amongst web-based, digital labour platforms there are a range of business models and services offered, from higher-skilled, "macro-task" platforms where workers offer their services as graphic designers, computer programmers, statisticians, translators, and other professional services, to "micro-task" platforms which typically involve clerical tasks that can be completed quickly and require less specialized skills. Common tasks on micro-task platforms include: copywriting and other forms of content creation for websites; visiting websites or downloading apps to increase traffic and search optimization ("content access"); product categorization; verifying and validating data (e.g., verifying a Twitter account is for a real person); content moderation (the removal of pornography or violent images before they are uploaded on social media accounts); writing (fake) reviews, text or audio transcription; and filling out surveys, either for market research or academic purposes (Berg et al., 2018).

Well-known macro-task platforms include Upwork, Freelancer.com, and Jovoto, though there are scores more, operating for different languages and markets, and specializing in particular fields. Macrotasks tend to be longer-term projects that typically require specialized skill sets such as IT programming or graphic design. Most of these platforms are designed so that workers set up individual profiles, indicate their expertise and their rate, with the final price for their work set via a bargaining process with the clients. In addition, there are also competitive, contest platforms, both in graphic design (99 design, Hatchwise) and computer programming (Topcoder, HackerRank) whereby workers compete with one another to develop design ideas or solve complex programming problems within a designated time, with the winner(s) chosen by the clients to receive the award. 
Micro-task platforms are more one-sided. Clients post tasks on the platform, either directly using an application programming interface (API), or through the platform company which breaks up the work into micro-tasks and then uploads it onto the platform. Workers see the task posted and as long as they have the right qualifications (usually a minimum threshold for their rating and experience, though they may also be required to pass unpaid qualification tests), can access the job, complete it and submit it. Prices are set by the client or platform and there is no negotiation.

While 'macro-task workers' exercise much greater independence than 'micro-task' workers, they are still subject to control and dependency on the platforms and in an unequal bargaining position with the client. In some instances, their work is directly monitored. For example, the freelancing platforms Upwork and Freelancer.com offer clients the option of paying workers by the hour or for the specific job. If paying by the hour, the workers are asked to download software that tracks their keystrokes and are also subjected to random screenshots in order to prove that they are working. An ILO survey of 1,000 platform workers in Ukraine found that $27 \%$ had downloaded this special software (Aleksynska et al., 2018).

Algorithmic management. Another important characteristic of digital labour platforms is "algorithmic management," defined as work settings in which "human jobs are assigned, optimized, and evaluated through algorithms and tracked data" (Lee et al., 2015, p. 1603). Möhlmann and Zalmanson (2017) delineate five characteristics of algorithmic management: (1) continuous tracking of workers' behaviour; (2) constant performance evaluation of workers; (3) the automatic implementation of decisions, without human intervention; (4) workers' interaction with a "system" rather than humans, depriving them of opportunities for feedback or discussion and negotiation with their supervisor; and (5) low transparency. The low transparency reflects in part a choice by enterprises to not disclose how the algorithms work, but it also reflects the adaptive nature of the algorithms, whereby the decisions change according to the data being collected (Möhlmann and Zalmanson, 2017).

On digital labour platforms, algorithmic management reaches beyond directing work and scheduling to control almost all aspects of the job. It not only makes this type of work possible, but shapes the workers' experience. This is true of both web-based crowdworking platforms (Amazon Mechanical Turk, Upwork), as well as location-based digital labour apps that direct workers to deliver local services, including in 
transport (Uber, Lyft), food delivery (Foodora, Deliveroo, Glovo) or inhome furniture assembly (Task Rabbit).

Some microtask platforms allow requesters to use an application programming interface (API), so that they can automatically send their data request to the platform directly. The task is then posted on the platform, which the workers can access. Serving as an intermediary, the microtask platform APIs make it possible to fully automate a process for businesses (Berg et al., 2018).

\section{Opportunities and risks for workers on web- based, digital labour platforms}

In 2015 and 2017, the ILO conducted a survey on five leading, English-language micro-task platforms: Amazon Mechanical Turk (AMT), Clickworker, Crowdflower (since renamed Figure Eight), Microworker and Prolific ${ }^{3}$ to learn more about workers' experience. The final sample included 3500 completed questionnaires from workers residing in 75 countries. The survey responses provide information on the socio-demographic characteristics of the workers, their reasons for entering crowdwork, their financial situation, their working conditions, as well as the different work experiences of women and men crowdworkers.

One of the principal advantages to working on digital labour platforms is the flexibility that it can provide to workers, who can choose when, where, and how they would like to work (Ipeirotis and Horton, 2011; Barnes et al., 2015). As a result, workers with disabilities or caring responsibilities - as well as residents of rural or economically depressed areas - are highly represented amongst crowdworkers (Zyskowski et al., 2015; Berg et al., 2018; Aleksynska, Bastrakova and Kharchenko, 2018). The ILO survey found that about 8 per cent of the workers could only work from home and about 21 per cent of the workers preferred to work from home (Berg et al., 2018). The qualitative information that the respondents revealed that care responsibilities, whether for children, the disabled or elderly, restricted many of these workers from undertaking tasks outside home. About 21 per cent of the female workers in the sample had small children (0-5 years), ranging from 15 per cent in Northern America to 42 per cent in Latin America and the Caribbean.

${ }^{3}$ For more details on the survey and the results see Berg, 2016, and Berg et al., 2018. 
Apart from care responsibilities, another reason why the respondents preferred to work from home or could only work from home was due to health problems or disabilities. For about 10 per cent of the respondents their health conditions affected their ability to carry out their day-to-day activities. Thus, work on digital labour platforms was an important source of income for many workers. Indeed, for one out of every three workers in the sample, work on digital labour platforms was their main source of income. Yet while crowdwork provides the flexibility and opportunity for such workers to carry out tasks, there are some important areas of concern with regard to remuneration and social security coverage, availability of work, and dispute settlement mechanisms.

Remuneration: One of the major concerns among crowdworkers has been low remuneration. As platforms classify workers as 'independent contractors', 'freelancers' or 'self-employed', the workers are not covered by minimum wage legislation or other forms of labour protection (De Stefano, 2016). The ILO 2017 survey showed that the average hourly earnings ranged between US\$2 (CrowdFlower) and US\$6.5 (AMT, US), with the distribution of hourly paid and unpaid work skewed towards the left (less pay) (Figure 1). As a result, a high proportion of workers earn below the average wage per hour of the respective platform: 58 per cent for Prolific; 59 per cent of American workers on AMT; and around 70 per cent of workers in CrowdFlower, Clickworker, Microworkers and Indian workers on AMT. In addition, the "typical" (median) worker earns much less than the platform average (US\$2.16 across all platforms), which means that half of the workers earn less than US\$2.16 per hour for time they spend working. 
Figure 2: Distribution of hourly paid and unpaid work among workers, by platform, 2017 (in US\$). (Source: ILO survey of crowdworkers, 2017).

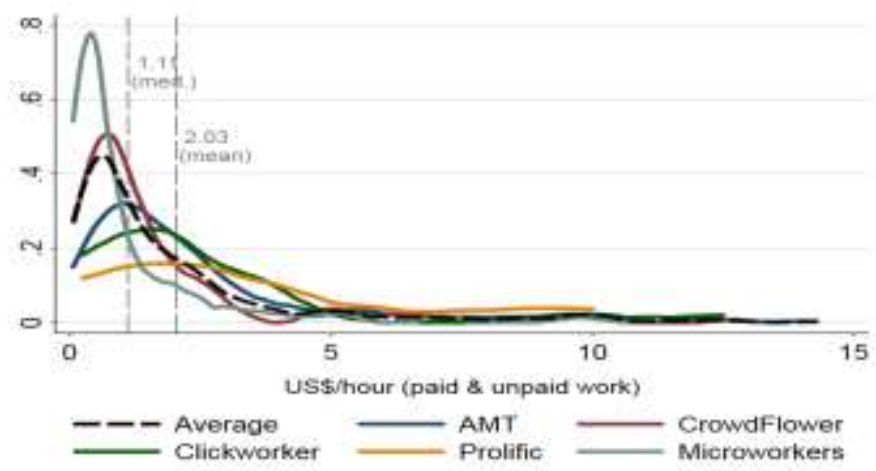

Note: Data trimmed at 1 and 99 per cent by platform. Vertical dashed lines indicate mean of the platform.

As such, a high proportion of workers were found to earn below the prevailing minimum wage in their jurisdiction, a finding also documented in other studies (Hara, et al., 2018; Huws, et al., 2017). In 2017 on AMT, about 48 per cent of American workers earned less than the federal minimum wage of US $\$ 7.25$ when only paid work is considered, and these proportions increase to 64 per cent when unpaid work is taken into account. Similarly, the German-based platform Clickworker advertises that workers on average can earn US $\$ 9$ per hour, corresponding to the German minimum wage of $€ 8.84$ per hour as of 1 January 2017. However, the average wage on Clickworker was US $\$ 3.2$ per hour; only 7 per cent of the survey respondents reported earning US\$9 or more per hour of paid work.

Availability of work: The low earnings among these workers is also due in part to their inability to obtain tasks on a continuous basis and the unpaid time that workers spent identifying suitable tasks. On average, in a typical week the workers spent 24.5 hours performing crowdwork, of which 18.6 hours were paid work and 6.2 hours were for unpaid work (e.g. looking for tasks, earning qualifications by taking screening tests, researching requesters through online forums, communicating with requesters, performing unpaid or rejected tasks or tasks that were ultimately not submitted). This means that for every hour spent on paid work, roughly one-third (20 minutes) of additional 
time was spent doing unpaid work. The time spent searching for work was also reflective of the lack of work available - and the oversupply of workers. Eighty-eight percent of respondents stated that they would like to do more work; wishing on average for 12 hours of more crowdwork per week.

The irregularity of work and differences in time zones meant that many workers worked long hours and atypical hours. Overall 52 per cent of the workers reported that they work at least six days per week, with 16 per cent working regularly for 6 days per week and 36 per cent working for 7 days per week. A large proportion of workers worked during the night (10 p.m. to 5 a.m.; 43 per cent) and during the evening (6 p.m. to 10 p.m.; 68 per cent), either due to availability of tasks or other commitments. About 18 per cent of the workers reported working in the night (more than 2 hours) for more than 15 days per month. There is also evidence from other studies of workers adapting their working time to the availability of task, which are often posted for during US business hours, which is evening or night-time for workers in Asia (O'Neill, 2018; D' Cruz and Noronha, 2016; Gupta et al., 2014). Furthermore, about 44 per cent of workers reported working for more than 10 hours in a day for about one-third of the month (1-10 days); and 23 per cent reported working such long hours for about 11-30 days in a month. This process of outsourcing work has stretched the number of consecutive hours of work both paid and unpaid - often eroding the fixed boundaries between home and work.

Rejection of work and dispute settlement mechanisms: Another reason for low remuneration is due to rejection of work performed. On many platforms' requesters (clients) can reject work and thereby refuse payment with little or no justification, while still keeping and retaining the benefit of the completed work. This was a major concern of the respondents, which they deemed in many cases to be unfair. Almost nine out of ten workers noted they had work rejected, and in consequence that the work was not remunerated. Often, little or no justification for rejections was provided. While some rejections may have been justified, in that the worker did not follow the instructions properly or made mistakes, often the reason lay beyond the worker's responsibility, for instance if instructions were unclear, if there was a mistake in the task design, technical errors or simply dishonesty (McInnis et al. 2016). In addition, the algorithmic management built-in to many platforms means that if three workers perform a particular task (a common practice for dispersing work on micro-task platforms), and the result of one of the workers is different from the other two, the algorithm 
may be set up to reject the work of the response that is different, even if it was correct. Such a rejection not only affects the workers' income, but also their ratings and reputation on the platform. When workers reach a certain threshold of rejections, they may not be eligible for better paid tasks and risk being deactivated from the platform. For example, on AMT a standard criterion used to attribute work to workers is an approval rate of at least 95 per cent. On Microworkers, workers whose approval rate ("temporary success rate") falls below 75 per cent are prevented from performing jobs for the next 30 days.

The lack of transparency and recourse mechanisms for these rejections is an important source of concern. Workers - and sometimes even requesters - often do not know why their work was rejected, due to the 'black box' nature of the algorithms (Pasquale, 2015). Yet the nonresponsiveness on the part of the requester is problematic, not just because of how it affects the worker's reputation and future earnings, but also because the worker does not receive the feedback needed to improve future performance, if a mistake was being made. On most platforms, there is no mechanism through which the worker can know why the work was rejected, and contesting such a decision is difficult. As Professor Lilly Irani, who has studied the operation of crowdworking platforms for over a decade explains: "Amazon does not require requesters to respond and many do not; several requesters have noted that a thousand-to-one worker-to-requester ratio makes responding cost prohibitive" (2015, p. 228). One large-scale requester explained to Professor Irani: "You cannot spend time exchanging e-mail. The time you spent looking at the e-mail costs more than what you paid them. This has to function on autopilot as an algorithmic system ... and integrated with your business processes" (personal communication, cited in Irani, 2015, p. 228).

Social protection: Apart from low remuneration, the social protection coverage of crowdworkers was quite low, and was another major concern among the workers. The ILO survey found that one-third of the crowdworkers are covered by some form of social protection, and women had less access to social protection than men. About 35 per cent of the crowdworkers in the survey had some form of pension or retirement plan and 29 per cent received government assistance, with a higher proportion of men compared to women having access to it. Workers who did have health or pension coverage received those benefits through another job, their spouses' employment, or the state. Among American workers on the Amazon Mechanical Turk platform, 91 percent of workers who were performing crowdwork as their main job were not contributing to social security (Berg, 2016). The Social Protection Floor 
Recommendation, 2012 (no.202) calls for all workers to have a basic level of social security throughout their lives, ${ }^{4}$ and technology can be effectively used and harnessed to ensure portability of social protection and in ensuring payment of social security for those working on digital platforms.

Charging fees to workers: Another troublesome finding is the practice of the leading freelancing platforms' decision to charge workers a commission for working on the platform. At Upwork, fees are typically set on a sliding scale from 20 to 5 per cent depending on the remuneration for the project and the worker's experience on the platform. ${ }^{5}$ An ILO survey of 1,000 platform workers in Ukraine found that the vast majority of online platform workers (85 per cent) pays a commission to the platform on which they work. Almost two thirds (62 per cent) always pay a commission, and a quarter (23 per cent) pay it from time to time (Aleksynska et al., 2018).

The prohibition of charging of fees to workers has been the subject of numerous international labour standards, and is central to the principle that "labour is not a commodity" (De Stefano and Wouters, 2019). The Protection of Wages Convention, 1949 (No. 95), and the Private Employment Agencies Convention, 1997 (No. 181) dissuade the practice of charging fees to workers. The Protection of Wages Convention, 1949 (No. 95) states that "Any deduction from wages with a view to ensuring a direct or indirect payment for the purpose of obtaining or retaining employment, made by a worker to an employer or his representative or to any intermediary (such as a labour contractor or recruiter), shall be prohibited" (Art. 9). Similarly, Article 7 of the Private Employment Agencies Convention, 1997 (No. 181) states that "Private employment agencies shall not charge directly or indirectly, in whole or in part, any fees or costs to workers."

\section{Potential difficulties in regulating digital labour platforms across multiple jurisdictions}

As a result of the problematic working conditions and low pay common to platform work, crowdworkers and trade unions around the world have turned to the courts in order to invoke the protections of

\footnotetext{
4 Social protection floors should be part of national strategies to ensure progressively higher levels of social security to as many people as possible, guided by ILO social security standards.

5 https://www.upwork.com/blog/2016/05/upwork-pricing/
} 
labour and employment law. Currently, cases are being heard around the world on the question of the employment status of platform workers. Most of these cases pertain to work being performed locally within a particular jurisdiction, with a focus on ridesharing companies, food delivery services, and similar "courier"-type services.

These court cases have turned on local or national definitions of "employee" and "independent contractor." Employees can claim various legal rights, such as minimum wages, unemployment benefits, leaves, and anti-discrimination protections. However, most legal systems do not protect independent contractors or self-employed workers in the same way; as separate businesses and service providers outside the firm, independent contractors are generally viewed as having the bargaining power to protect themselves through contract. Thus, this classification issue has turned out to be an important "gateway" or threshold that must be met before employee litigation against platforms can continue. (Cherry \& Aloisi, 2017).

The legal tests that are used to distinguish and define employees as opposed to independent contractors may vary among jurisdictions. Some of the legal tests used attempt to define "control," to look at the amount of bargaining power or market "subordination," while others examine indicia of entrepreneurial activities and the opportunity for gain or loss that the worker may exercise (Cherry, 2015). In 2018, the Supreme Court of California made headlines with its Dynamex decision, when it adopted a new test for employee classification that was more favourable to finding employee status. The so-called ABC Test adopted in Dynamex lists three factors that are required for a business to prove in order to classify a worker as an independent contractor. The first factor is whether the worker is free from control of the hiring entity. The second factor requires that the worker perform work outside of the hiring entity's business. The third factor requires that the worker is engaged in an independent trade, occupation, or business. The burden of proving these three elements is placed on the hiring entity; and even missing one of the three elements is enough to result in a finding of employee status. As such, Dynamex made it easier for workers to establish their employee status. However, there were many questions left open after the decision, which only applied to wage laws. And because the Dynamex case involved traditional business, i.e. an offline courier service, some commentators questioned whether the factor tests it announced would apply to on-demand gig work.

Since the Dynamex decision, digital platforms, traditional businesses, labour unions, and workers have all lobbied the California 
legislature for clarification as well as to advance various policy positions. The ultimate result was California Bill AB5, which was passed by the Legislature in September 2019, and which Governor Newsom pledged to sign and enact into law. AB5 makes it clear that the Dynamex ABC test remains the new standard for determining classification issues in California. Further, AB5 expanded the scope of the Dynamex ruling, applying it to contexts beyond wages, including unemployment benefits, sick days, parental leave, and other areas of the California Labor Code. Finally, it was clear that the legislative intent was to reach on-demand and gig companies; they were not included in the "carve outs" present in the bill for certain professions, such as physicians, attorneys, engineers, and securities brokers. In the wake of the bill, Uber and Lyft have threatened to use vast resources to propose a referendum that could amend the law to reflect a "third category" of worker that would have less than full employment rights. (Chen, 2019).

If this were not complicated enough, gig work seems to harbour some of the elements of the various legal tests, while lacking others. Common factors under the "control" test might include the right to dictate the hours of work, the supervision of work product and lack of creative control. Gig workers might be able to sign onto a cellphone app at various hours of their choosing, which makes them look more like independent contractors. However, gig workers have their output closely monitored by GPS, keystroke recording, or wearables. The "algorithmic boss" may ask customers or others to use rating systems, or employ other methods that are consistent with constant surveillance and total control. Thus, many of the legal tests have mixed results with some factors that lean toward employee status, but others that lean toward independent contractor status. As noted by a judge in the Northern District of California, attempting to find the right classification for gig workers is like "trying to fit a square peg into a round hole." (Cherry, 2015).

This confusion over the tests has led to inconsistent results for the classification of workers on digital platforms. In some jurisdictions, such as Belgium, gig workers have been ruled to be employees because of the amount of subordination and dependence involved in the relationship. In other jurisdictions, like Turin, Italy, labour tribunals have ruled that gig workers are independent contractors because of the ability workers have to choose their own schedules and sign onto and off of the webpage or cellphone app. In the United Kingdom, the Employment Appeals Tribunal found that Uber drivers fit best into an "in between" intermediate category known as "workers" that has some of the rights and benefits of employees, such as the right to the national minimum 
wage, but not other rights such as protection against unfair dismissal (Cherry, 2019).

Inconsistent legal rulings showcase the difficulty that courts have had in applying traditional classification tests to the new setting of the on-demand economy. Cases concerning on-demand work via cellphone app or web platform currently continue to move forward in many national jurisdictions, including South Africa, Spain, Brazil, and Australia. Even with initial decisions from trial courts, any definitive answer on the classification question of gig workers will not emerge from supreme courts or national legislatures immediately. Rather, this will be a slow process involving appeals and potential legislation within many countries, as interest and advocacy groups meet and marshal their resources to challenge court rulings they find objectionable.

While there are currently many cases pending about the status of Uber and Lyft drivers, to date, only one case, Otey v. Crowdflower, filed in a U.S. district court in California, has involved a platform specializing in digital microtasks. This 2013 case featured remote online workers who alleged they were paid less than the federal U.S. minimum wage of $\$ 7.25$ as well as less than the applicable state minimum wage. Joining together into a class action, the crowdworkers brought a case under U.S. minimum wage laws against the web-based digital labour platform Crowdflower. ${ }^{6}$ Otey was an outlier in that it only attempted to consolidate the claims of workers in two states, and the company involved was headquartered in one of those states, so no jurisdictional issues or conflict of law issues were implicated. Ultimately, the case settled out of court with Crowdflower paying the crowdworkers backpay to bring them up to minimum wage, and no rule or precedent was established about the status of digital platform workers.

Perhaps given the differences in labour regulation by jurisdiction, it is not surprising that the conclusions reached across jurisdictions about the classification and status of gig workers on cellphone apps have varied. ${ }^{7}$ Yet for web-based digital labour platforms whose work involves cross-border transactions - with the platform company located in one country, the client/requester in a different country, and the workers spread throughout the world - the different legal decisions reached across jurisdictions set the stage for inconsistent rulings and conflicts of

\footnotetext{
${ }^{6}$ Workers sued the company for failure to pay minimum wage under the FLSA and Oregon's minimum wage law. The case was settled before a judgement could be made.

7 See https://ignasibeltran.com/2018/12/09/employment-status-of-platform-workersnational-courts-decisions-overview-australia-brazil-chile-france-italy-united-kingdomunited-states-spain/\#\%C3\%ADndice for an overview of national court decisions.
} 
law (Cherry, 2019; Pretelli, 2018). The issue is not just about legal classification of workers, but will reach more deeply to questions of the proper minimum wage, social insurance, anti-discrimination, and safety regimes, all of which vary widely across national jurisdictions.

These problems are ubiquitous with web-based, digital labour platforms. As examples, consider the Upwork platform, which collects and parcels out digital tasks including graphic design, computer programming, and data entry. Upwork as a company is headquartered in Mountain View, California, in the United States. Some of Upwork's clients/requesters live in the United States, but many are domiciled in other nations. Similarly, some of the digital workers who perform tasks on Upwork platforms may live in the U.S., but others live in Europe, Asia, or South America. To take another example, consider the platform Chatterbox, which is headquartered in the U.K. Chatterbox's business is to provide language lessons and tutorials, and it does so by hiring workers who live in international refugee camps. The users who pay for Chatterbox's language lessons are located across the world. Figuring out the proper legal regulations to apply to workers in these cross-border situations will create difficult legal problems.

The dispersal of workforce and requesters may lead to problems in legal compliance for digital platform operators. Currently, courts and legislatures are attempting to determine if existing laws apply to platforms, or perhaps what new laws will need to be passed to close gaps or loopholes in regulation. While the gaps in regulation seem favourable to businesses right now, as jurisdictions begin to pass regulations, it may cause problems if those regulations are inconsistent. As countries begin to address the current absence of regulation, lack of uniformity will be the most likely result. Under these circumstances, the need to calculate minimum pay rates across multiple jurisdictions or to comply with various procedural and administrative rules will likely result in timeconsuming and potentially costly labour compliance issues for platforms.

The geographical dispersion of transactions across the platform work creates the potential for bringing legal action against a platform in any of the jurisdictions in which the platform's clients and workers are based. As such, the potential for "private international law" or "conflict of law" disputes arise. Courts first need to determine whether they have jurisdiction, the ability or competence to hear a case. Courts also need to figure out if the location of the court, or forum, is proper and best suited to the case being heard. Courts must then determine which jurisdiction's laws apply before they turn to resolving the underlying dispute (Cherry, 
2019). ${ }^{8}$ If the potential laws from various nations that could apply are in conflict, difficult legal issues present themselves.

As disputes about the crowdwork and the gig economy are decided, and have inconsistent results, as we are seeing presently, the stage is set for worrisome and potentially costly, litigation. The regulation of digital platform work on a national level will incentivize all relevant parties to select the jurisdiction in which to file a legal action where the laws are most favourable to them (e.g. the country where the worker resides or works, the country where the platform has its headquarters, or the country where the client is located). Platforms may seek to exert influence in this regard by choice of law or choice of forum clauses in their online terms of service. In legal terms this is known as 'forum shopping,' and it may lead to inconsistent and sometimes conflicting frameworks that create additional problems.

National-level regulation that aims to strengthen the rights and benefits of workers on web- based, digital labour platforms, for example by requiring platforms to contribute to social security systems or by applying local minimum wages, could also face compliance issues. Moreover, implementing national regulations risks creating a competitive disadvantage for workers located in that country. Some advocates for crowdworker rights are concerned that if national standards are raised in some countries, platforms would slow or stop accepting workers from those countries.

As such this could create a risk of a "race to the bottom" in labour standards, in which no country wants to be the one to regulate a new form of work and potential drive away potential earnings from its citizens. Yet, without action by some regulatory body, none of the crowdworkers will be properly protected. While it might be in the best interest of all workers on digital labour platforms to have some form of minimum regulation, such a race to the bottom could prevent those basic protections from being enacted. The next section posits that international regulation is the only way to surmount these collective action problems.

\footnotetext{
${ }^{8}$ Cherry reviews conflict of law issues emerging in California, US, EU and India (Cherry,
} 2009, p. 21). 


\section{An international governance system for digital labour platforms}

Recognizing these jurisdictional and regulatory difficulties, the ILO's Global Commission on the Future of Work called for the "development of an international governance system for digital labour platforms that sets and requires platforms (and their clients) to respect certain minimum rights and protections." (ILO, 2019, p. 44). The Commission further noted that the Maritime Labour Convention, 2006 (MLC, 2006) is an important precedent, as it too concerns an industry with multiple parties operating across different jurisdictions. Despite this regulatory challenge, governments and social partners through the MLC have managed to establish and apply a global labour code for seafarers.

In fact, the history of the MLC sheds some light on why an international regulatory structure was needed for maritime work. In the nineteenth century, a seafarer's life was a difficult one, with few, if any safeguards against wage theft, safety hazards, or poor working conditions. At that time, the dominant international law regulating the seas was the centuries-old concept of freedom of the seas - mare liberum. Yet as the volume of goods shipped at sea increased, so too did concern over potentially exploitative or poor working conditions (Mangone, 1997). In extreme situations, workers could find themselves abandoned at foreign ports with unpaid wages, no passage to return home, and no legal recourse in the foreign country's courts (Link, 2015).

Beginning in 1897, the International Maritime Committee (IMC) began advocating for greater unification of maritime law, and adopted regulations and protocols to further harmonization (Wiswall, n.d.). In the ensuing years, the IMC began to fashion the standards and organization necessary to provide cooperation between seafaring states. As the years passed, the task fell to the ILO, which passed sixty-plus instruments regulating various employment and working conditions for seafarers (Frawley, 2011). In 2006, the ILO's International Labour Conference took up the project of consolidating and modernizing the maritime employment instruments into the Maritime Labour Convention (MLC). ${ }^{9}$

Under the MLC, every seafaring worker has a right to a safe workspace that complies with international standards, fair terms of employment, medical care, and decent living conditions. These rights are

9 Maritime Labour Convention, Preamble, Feb. 23, 2006, 2952 U.N.T.S. 5. See also Chirstodoulo-Varotsi, 2012. 
set out in five titles under Article IV. Title I sets forth minimum and basic requirements, such as age requirements, adequate training, and employment notification standards. Title II covers the conditions of employment, including notice of termination periods, regular wage payment and calculation, hours, leave, repatriation, and compensation. Title III concerns decency of accommodation and recreation, including quality of food served aboard. Title IV ensures adequate healthcare provisions, places liability for workers' health on the owner of the ship, requires safety standards to be followed, and provides for social insurance for seafarers. Finally, Title V discusses the enforcement of the other titles, including the responsibilities of flag and port states.

Since its promulgation in 2006 and entry into force in 2013, the MLC can by all accounts be considered a success. As of February 2019, 82 Member States have ratified the convention, covering over 90 percent of the tonnage shipped. Because ships can be checked and reviewed both when they exit as well as when they enter a signatory jurisdiction, it enlarges the regulatory coverage of the MLC. There are significant penalties for violating the MLC that can be implemented in real time, on the ground. For example, a ship's cargo can be impounded or sailing can be delayed until wage claims by maritime workers have been satisfied, or deficiencies in living conditions or food have been rectified. As such, the MLC ensures that there is a level playing field that affords protection to maritime workers around the world.

Maritime employment law has important parallels to crowdwork on digital platforms. One of these similarities is the temporary, task, or project-based nature of the work. Seafarers would hire on for a one-time voyage, and would be paid by the voyage, at the end of the voyage. Similarly, many online crowdworkers are paid by piece-rate or by the project or task when the task is completed. Historically, maritime work had a serious risk of wage theft. Sailors were often not paid, and stranded in foreign nations. Unfortunately, due to the current structure of many forms of digital labour platforms, wage theft issues are also present for online crowdworkers. Both forms of work come along with the risk of social isolation; sailors would often be separated from home and loved ones for extended periods. Online workers, typically working singly from home offices, may have little social contact with colleagues.

The most important parallel between maritime labour and online crowdwork, however, is the many different jurisdictions implicated as a result of the international nature of the work being performed. In maritime employment, the workers themselves (along with the goods or passengers being transported) are in motion from one country to another, 
often passing through other nation's waters. Workers may join on or leave at different ports, as their contracts are fulfilled. In the case of online crowdworkers, work is being generated, sent, processed, and stored in many different locations. Fellow workers are located around the world, and so are requesters. Data, which some technologists have termed the "new oil" because of its value after being refined or manipulated, is being shipped, transformed, exported and imported across nations.

In fact, many digital platforms are seeking to become true "global marketplaces" for labour, with the Internet collapsing national borders and boundaries. Understanding these goals of many digital platforms, there may be a need for an international sectoral regulation of crowdwork or other form of international governance mechanism. As such, crowdwork might benefit from the type of international, sectoral regulation that exists in maritime employment.

Such sectoral regulation of crowdwork would necessarily entail regulations specifically crafted and tailored to fit the requirements, special issues, and needs of online crowdworkers. Like the port authorities that can check for compliance with the MLC and impound cargo in the event of labour violations, various host, server, or entry points could be checked for compliance in crowdwork. Because the workers behind the platform are largely invisible, such regulatory checks might involve a sharing of data between platform operators, regulatory authorities, and the workers themselves. This would comport with the beginnings of data protection laws, such as the recently passed European Union's General Data Protection Regulation (GDPR). Such measures would also provide workers with the ability to contest rankings or ratings that they find to be erroneous, and it might also allow workers to use portable data across platforms.

Another source that might be helpful to consider in the international regulation of digital labour platforms would be the ILO's Tripartite Declaration of Principles concerning Multinational Enterprises and Social Policy (MNE Declaration), 2017. The MNE Declaration provides guidance to multinational enterprises on social policy and inclusive, responsible, and sustainable workplace practices. It defines multinationals as including enterprises which control services outside the country in which they are based. Platforms could use the guidance provided in the MNE Declaration to develop clear codes of conduct for members, including published procedures for workers to raise their concerns. 
One interesting development in this respect is the "Ombuds office for the Crowdsourcing Code of Conduct" established in 2017 by the German trade union, IG Metall, the German Crowdsourcing Association, and eight digital labour platforms. These eight platforms, headquartered in Germany and the United Kingdom, but with legal presence in other European countries and operations that span the globe, had signed a voluntary Code of Conduct. ${ }^{10}$ The code of conduct sets out a basic set of guidelines with a view to promoting trust and fair cooperation between service providers, clients and crowdworkers. The mandate of the Ombuds office is to enforce the Code of Conduct and resolve disputes between workers and signatory platforms, regardless of the location of the worker. The Ombuds office is composed of a board of five people one worker, one trade union representative, a platform representative, one Crowdsourcing Association representative, and a neutral chair - and resolves disputes by consensus, with IG Metall handling the administration. As of January 2019, the Ombuds office of the Code of Conduct had resolved 23 cases submitted by workers via its online form. 11

Given important concerns about lack of dispute settlement mechanisms available for workers on digital labour platforms, the bipartite Ombuds office is an important initiative. It is also a good example of 'virtual' labour market governance, as all activities, including discussions and decisions of the board, are conducted online.

International regulatory standards, as called for by the Global Commission on the Future of Work, could set minimum requirements as well as develop the infrastructure necessary for facilitating payments to national social security systems to provide for worker income security. Such standards could also encompass the establishment of a representative board that would adjudicate disputes between platforms, clients and workers.

\section{Conclusions}

Technology has had a significant impact on the way work is designed, implemented, broken down, and assigned. Crowdwork that takes place on digital labour platforms has been one result. The growth of digital labour platforms that draw requesters and workers from around the world has presented serious challenges to nationally-based

\footnotetext{
$10 \mathrm{http}: / /$ crowdsourcing-code.com/

${ }^{11}$ See http://ombudsstelle.crowdwork-igmetall.de.
} 
traditional systems of labour and employment regulation. If current trends continue, we could see situations in which inconsistent legal rulings are reached in courts around the world. Conflicts of law problems are sure to follow, and many resources will be spent by workers and platforms in forum shopping. Further, as nations continue to regulate and courts continue to make decisions, platforms may find -- even without litigation -- that it is difficult to comply with the laws in the various nations that might have jurisdiction over them.

In fact, legal systems developed around geographical borders may not make sense when confronted with the global network that comprises web-based digital labour platforms. Where transactions are virtual and extra-territorial, national systems designed for an analogue world may fall short of their aims. Worse yet, collective action problems may hamper nations from even attempting to ensure the most basic minimum standards for online work.

If we are to ensure decent work for all, including those working on digital labour platforms, then we must devise mechanisms that respond to this new form of work. Drawing on the previous precedent of maritime workers, one policy intervention is to examine a sectoral approach. Just as maritime work was seen as involving multiple countries and seemed impossible to regulate in the nineteenth century, so does crowdwork today. With international cooperation, these goals are within reach. The MLC and other ILO documents provide a framework and way forward to begin the process of the international regulation and standard setting needed for crowdwork on digital labour platforms.

\section{References}

Agrawal, A.; Horton, J.; lacetera, N.; Lyons, E. 2013. Digitization and the contract labor market: A research agenda, NBER Working Paper No. 19525 (Cambridge, MA, National Bureau of Economic Research).

Aleksynska, M., A. Bastrakova, N. Kharchenko (2018) Work on digital labour platforms in Ukraine: Issues and policy perspectives, ILO, Geneva.

Barnes, S-A.; Green, A.; de Hoyos, M. 2015. "Crowdsourcing and work: Individual factors and circumstances influencing employability", in New Technology, Work and Employment, Vol. 30, No. 1, pp. 16-31.

Berg, J. 2016. "Income security in the on-demand economy: Findings and policy lessons from a survey of crowdworkers", in Comparative Labor Law and Policy Journal, Vol. 37, No. 3, pp. 543-576.

Berg, J., M. Furrer, E. Harmon, U. Rani and M.S. Silberman (2018) Digital labour platforms and the future of work: Towards decent work in the online world, ILO, Geneva. 
Cherry, M. (2019). "Regulatory options for conflicts of law and jurisdictional issues in the on-demand economy," Conditions of Work and Employment Series no. 106, ILO, Geneva.

Chen, A. (2019). "This is a Way Uber and Lyft Want to Get Around Making Drivers Employees," in MIT Technology Review, September 13, 2019.

Cherry, M. \& Aloisi, A. (2017). "Dependent Contractors in the Gig Economy: A Comparative Approach," in American University Law Review, Vol. 66, pp. 635-657.

Cherry, M. (2015). "Beyond Misclassification: The Digital Transformation of Work," in Comparative Labor Law and Policy Journal, Vol. 37, No. 3, pp. 576-603.

Choudary, S.P. 2018. "The architecture of digital labour platforms: Policy recommendations on platform design for worker well-being," ILO Future of Work Working Paper Series.

Chirstodoulo-Varotsi, I. (2012) "Critical Review of the Consolidated Maritime Labour Convention (2006) of the ILO: Limitations and Perspectives”, 43 J. MAR. L. \& COM. 467, 468 (2012).

Corporaal, G.; V. Lehdonvirta, (2017) Platform sourcing: How Fortune 500 companies are adopting online freelancing platforms, Oxford Internet Institute, August 2017.

D' Cruz, P and Noronha, E (2016), Positives outweighing negatives: The experiences of Indian crowdsourced workers, Work Organisation, Labour and Globalisation 10(1): 44-63.

De Stefano, V.; M. Wouters, "Should digital labour platforms be treated as private employment agencies?", ETUI Foresight Brief no. 7 (April 2019).Frawley, N. (2011) "A Brief History of the CMI and its Relationship with IMO, the IOPC Funds and other UN Organisations," Comité Maritime International (Jan. 7), available at http://comitemaritime.org/Relationship-with-UNorganisations $/ 0,27114,111432,00 . h t m l$

Gray, M.; S. Suri (2019) Ghost Work: How to Stop Silicon Valley from Building a New Global Underclass, Houghton Mifflin.

Gupta N, Crabtree A, Rodden T, Martin D and O'Neill J (2014) Understanding Indian Crowdworkers. Proceedings of the CSCW'14 Conference, Baltimore US, 15-19th February, pp.224235. New York: ACM press.

Hara, K.; Adams, A.; Milland, K.; Savage, S.; Callison-Burch, C.; Bigham, J.P. 2018. A data-driven analysis of workers' earning on Amazon Mechanical Turk, paper presented at the Association for Computing Machinery (ACM) Conference on Human Factors in Computing Systems (CHI), Montreal, 21-26 Apr.

Huws, U. et al. 2017. Work in the European Gig Economy. Research Results from the UK, Sweden, Germany, Austria, the Netherlands, Switzerland and Italy. (Brussels, Foundation for European Progressive Studies (FEPS)).

ILO, 2019, Work for a Brighter Future, Geneva, ILO.

Ipeirotis, P. 2010. "Analyzing the Amazon Mechanical Turk marketplace”, in XRDS, Vol. 17, No. 2, pp. $16-21$.

Kässi, O.; V. Lehdonvirta (2018) Online labour index: Measuring the online gig economy for policy and research, Technological Forecasting and Social Change, Volume 137, 2018, pages 241-248.

Min Kyung Lee, Daniel Kusbit, Evan Metsky, and Laura Dabbish, "Working with machines: The impact of algorithmic and data-driven management on human workers", CHI 2015: Proceedings of 
the 33rd Annual ACM Conference on Human Factors in Computing Systems, New York, ACM Press (2015).

Link, P. (2015) One Small Step for the United States May Be One Giant Leap for Seafarer's Rights, 33 HofsTRA LAB. \& EMP. L. J. 167, 174.

Mangone, G. (1997) United States Admiralty Law, Kluwer Law International.

Möhlmann, M.; L. Zalmanson, "Hands on the wheel: Navigating algorithmic management and Uber's autonomy," ProceEdings of THE INTERNATIONAL CONFERENCE ON INFORMATION Systems (ICIS 2017), Seoul, $10-13$ Dec.

McInnis, B.; Cosley, D.; Nam, C.; Leshed, G. 2016. Taking a HIT: Designing around rejection, mistrust, risk, and workers' experiences in Amazon Mechanical Turk, Proceedings of the 2016 CHI Conference on Human Factors in Computing Systems, San Jose, CA, 7-12 May, pp. 2271-2282.

O'Neill, J (2018) From Crowdwork to Ola Auto: Can Platform Economies Improve Livelihoods in Emerging Markets? In: Galperin H and Alarcon A (eds) The Future of Work in the Global South. Ottawa: International Development Research Centre, pp. 28-31.

Pasquale, F. 2015. The black box society: The secret algorithms that control money and information (Cambridge, MA, Harvard University Press).

Pretelli, I. (2018) Conflict of Laws in the Maze of Digital Labour Platforms/Le droit international prive dans le labyrinth des plateformes digitales, Publications de l'institut suisse de droit comparé, Genève/Zurich, Schulthess Editions Romandes.

Schmidt, F. A. 2017. Digital labour markets in the platform economy: Mapping the political challenges of crowd work and gig work (Bonn, Friedrich-Ebert-Stiftung).

Schmidt, F. A. 2019. Crowdsourced Production of AI Training Data: How Human Workers Teach Self-Driving Cars How to See. Hans Böckler Stiftung Working Paper No. 155, Aug 2019.

Wiswall, F.L., Jr, n.d., "A Brief History, Comité Maritime International," available at https://comitemaritime.org/about-us/history/ 